\title{
Comparison of Plant and Microbial Communities between an Artificial Restoration and a Natural Restoration Topsoil in Coal Mining Subsidence Area
}

\author{
Liu Ying, Lei Shaogang, Gong Chuangang, Bian Zhengfu
}

(School of Environment Science and Spatial Information, China University of Mining and

Technology, Xuzhou, 221116, China)

\begin{abstract}
Increased attention has been paid to the influence of coal mining subsidence on
ecological environment. Restoration of ecosystem in damaged mining area is critical for restoring disturbed environment. The comparing of plant communities and microbial communities in the artificial restoration and natural restoration areas provides an effective method for evaluating the restoration effects. However, such studies are limited in coal mining subsidence restoration areas.
\end{abstract} Subsidence area in Shendong mining area, located in the semi-arid region of Western China, was restored from 2003 with 5 ecological restoration plant species. In July 2017, the comparison and analysis of plant and microbial communities were conducted at the artificial restoration areas (AR) and the natural remediation areas (NR). The results showed that the artificial ecological restoration in Shendong mining area has achieved some success, but it has not recovered to a similar ecosystem before the destruction. A higher plant species, coverage and bacterial community diversity were observed in AR. However, these features have lower similarity compared with those in NR sites. Potential soil factors, such as $\mathrm{pH}$, moisture content, total carbon content, organic matter, nitrogen and bulk density, have a greater impact on soil bacterial community structure and diversity. In the ecological restoration of the mining area, attention should be paid to the 
restoration of soil properties in the mining area. This study can provide theoretical guidance for more scientific ecological restoration in the damaged mining area.

Key words: Artificial restoration; ecological restoration; coal mining subsidence; semi-arid; soil microbial community

\section{Introduction}

Large scale coal mining is contributing to deterioration of the ecosystem structure and function of the mining area (Ermite et al., 2004), especially in arid and semi-arid areas. Human beings have taken a series of measures to restore the service function of the destroyed ecosystem after coal mining completion. Re-vegetation is one of the major measures adopted for ecological environment management in mining area (Darina et al., 2003; Sheoran et al., 2010; Tordoff et al., 2000). Recently, the focus of coal resources mining is shifted to the west China, which makes the fragile ecological environment under very severe pressure and poses a great threat to the sustainable development of mining area economy (Shi et al., 2009; Qian, 2011). Under the background of sustainable development, ecological restoration in mining area has become a very urgent task. Maintaining the sustainable exploitation of mineral resources and land use has become the key development theme of the world mining countries (Worrall et al., 2009). In order to improve the ecological restoration effect of coal mining subsidence area and provide theoretical guidance for land reclamation and re-vegetation, it is necessary to investigate the effect of vegetation and soil restoration in subsidence area.

Essence of the restoration in coal mining subsidence area is to compensate for the disturbance of ecological system, to reduce the adverse effects on the environment and to make it safe for 
further use (Chen et al., 2017). In order to evaluate the restoration status of the subsided area in the mining area, the characteristics of the vegetation and microbial diversity, community structure, richness and similarity of the restoration area need to be compared with the control area (undisturbed natural area) (Gornish et al., 2017; Orsi et al., 2011; Perillo, 2009). Evaluating recovery results through the long-term basic observation study of the project is the key to evaluate the efficiency of alternative methods for mining area restoration (Auestad et al., 2016; González et al., 2016). However, the evaluation of ecological restoration success is difficult and critical. Coal mining subsidence area excellent systems for exploring restoration success because both restoration and natural areas are widely distributed and ecological restoration methods have demonstrated utility in these environments (Bi and Wu, 2006; Bian, 2013).

The ecological effects caused by mining disturbance have been paid close attention to by scholars (Du et al., 2003; Prach et al., 2011). Numerous studies have reported on the ecological restoration of coal mining subsidence areas around the world (Avera et al., 2015; Dunrud and Osterwald, 1980; Fieldsjohnson et al., 2012; Koch, 2010; Zipper et al., 2013) and in China (Hao and Qi, 2009; Hu et al., 2012; Li et al., 2015; Li et al., 2017; Qi et al., 2014; Zhou and Wang, 2014). Previous studies focus more on the methods and processes of ecological restoration in coal mining subsidence area. The methods and techniques of rehabilitation include re-vegetation (Tordoff et al., 2000), soil reconstruction (Krümmelbein and Raab, 2012), hydrological protection (Huang et al., 2012) and landscape planning (Dulias, 2010), etc. Particularly, a number of regional ecological restoration technologies have also been developed, for example, the United States Appalachian development forestry reclamation act (Wilsonkokes et al., 2013), India microbial 
assisted mining green technology (Juwarkar et al., 2009) and Chinese coal mining subsidence loess filling technology (Wang et al., 2014) and so on. However, artificial ecological restoration is always faced with the trade-off between cost and effectiveness (Kimball et al., 2015), and the effect of artificial restoration is not necessarily better than natural restoration (Tropek et al., 2012). Therefore, the ecological restoration of mines is faced with the problem of strategic choice between manual intervention and natural restoration. However, studies on comparison effect of artificial restoration area topsoil and a natural restoration area are scarce, especially in the semi-arid coal mining area.

Approaches to restoring mining ecosystem depend strongly on levels of forest and soil degradation and residual vegetation (Chazdon, 2008). The surface subsidence, soil erosion and vegetation degradation, caused by coal mining, have changed the soil water storage state, soil structure and vegetation growth environment (Lei et al., 2016; Yang et al., 2016). The nutrient cycle of natural or man-made terrestrial ecosystems, such as carbon, nitrogen, sulfur, etc., is mainly regulated by plants and associated microorganisms (e.g., bacteria for nitrogen fixation, nitrification and denitrification) (Chen et al., 2017; Parton et al., 2015). Plants get carbon and nutrients from the atmosphere and soil, and then transfer these substances to the rhizosphere, which are decomposed and mineralized by bacteria, releasing nutrients back to the soil and providing nutrients for plants (Chen et al., 2017; Schulze and Mooney, 1994). Thus, plants and bacteria play important parts in the restoration of the ecosystem of the mining area. The microbial community of surface soil is an important biological indicator to evaluate the ecological benefits of soil environment (Morris and Blackwood, 2015). However, the role of soil microorganisms in 
the ecological restoration of mines is often neglected by human beings. Comparing the similarity of the microbial community in the artificial restoration area and the natural restoration area, as a measure of ecological performance, is scarce and beneficial to provide a scientific theoretical guidance for ecological restoration in the mining area.

Shendong coal mine is the largest and most important coal base in semi-arid area of western China, serious ecological environment damage caused by coal mining subsidence. In order to restore the ecological environment, a series of restoration measures have been adopted, and many recovery areas are distributed in the mining area. In order to provide a theoretical basis for the sustainable development of the mine, it is necessary to compare plant and microbial communities between a coal mining subsidence and a natural restoration topsoil area. Based on this, the microbial and vegetation community characteristics, and soil site conditions in the restoration area were investigated. The aims of this study were (1) to investigate the similarity of soil properties, plant and microbial communities between an artificial restoration and a natural restoration topsoil in coal mining subsidence area; (2) to analyze the potential driving factors of soil bacterial communities between the artificial restoration area and the natural restoration surface soil area.

\section{Material and methods}

\subsection{Study sites}

This study was carried out in ecological restoration area of Shendong Coal Mine in eastern edge of Mu Us Desert, Ejin Horo Banner, the Inner Mongolia Autonomous Region, Western China (Fig.1). The study sites, with a total area of $376 \mathrm{~km}^{2}$ and an annual average temperature of $7.3^{\circ} \mathrm{C}$, were located within $110^{\circ} 05^{\prime} 00^{\prime \prime}$ to $110^{\circ} 20^{\prime} 00^{\prime \prime} \mathrm{E}$ and $39^{\circ} 27^{\prime} 00^{\prime \prime}$ to $39^{\circ} 15^{\prime} 00^{\prime \prime} \mathrm{N}$. The region is 
characterized by a typical arid and semi - arid continental climate of plateau with dry climate and low rainfall and annual average rainfall and evaporation amount are $413.5 \mathrm{~mm}$ and $2111.2 \mathrm{~mm}$, respectively. The main soil types are loess and aeolian sandy soil.

Investigated sites were primarily divided into two main categories: (1) artificial restoration area (AR) (7 repetitions); (2) natural restoration area (NR) (6 repetitions). Selected restoration areas were first - mined in 1995, and ended - mined in 1997, with a natural restoration history of more than 20 years. Coal mining had resulted in a great deal of permanent cracks on the surface of the earth, which had seriously damaged the ecological environment (Bian et al., 2016). The vegetation coverage and diversity of the mining area decreased obviously (Wang et al., 2006). In the artificial restoration area, capped and restored in 2003, many kinds of ecological restoration plants were planted to restore the diversity of the surface vegetation, for example, Amygdalus pedunculata Pall, Cerasus humilis, Pinus so on. In order to improve the survival rate of the restored plants, corresponding water conservation measures were taken at the root of the plant. At natural restoration area, where coal mining was stopped, no active human intervention occurred, such as planting or seeding. Particularly, in order to better reflect the effect of restoration and reduce the interference of human destruction, logging and herding were forbidden in these restoration areas. According to Gornish's method for selecting contrast areas, the natural areas were close to artificial restoration areas and no active exclusion of interference from other factors. These sites were similar to the vegetation structure and were likely to be exposed to similar degradation levels of the restoration zone prior to rehabilitation activities (Gornish et al., 2017). 

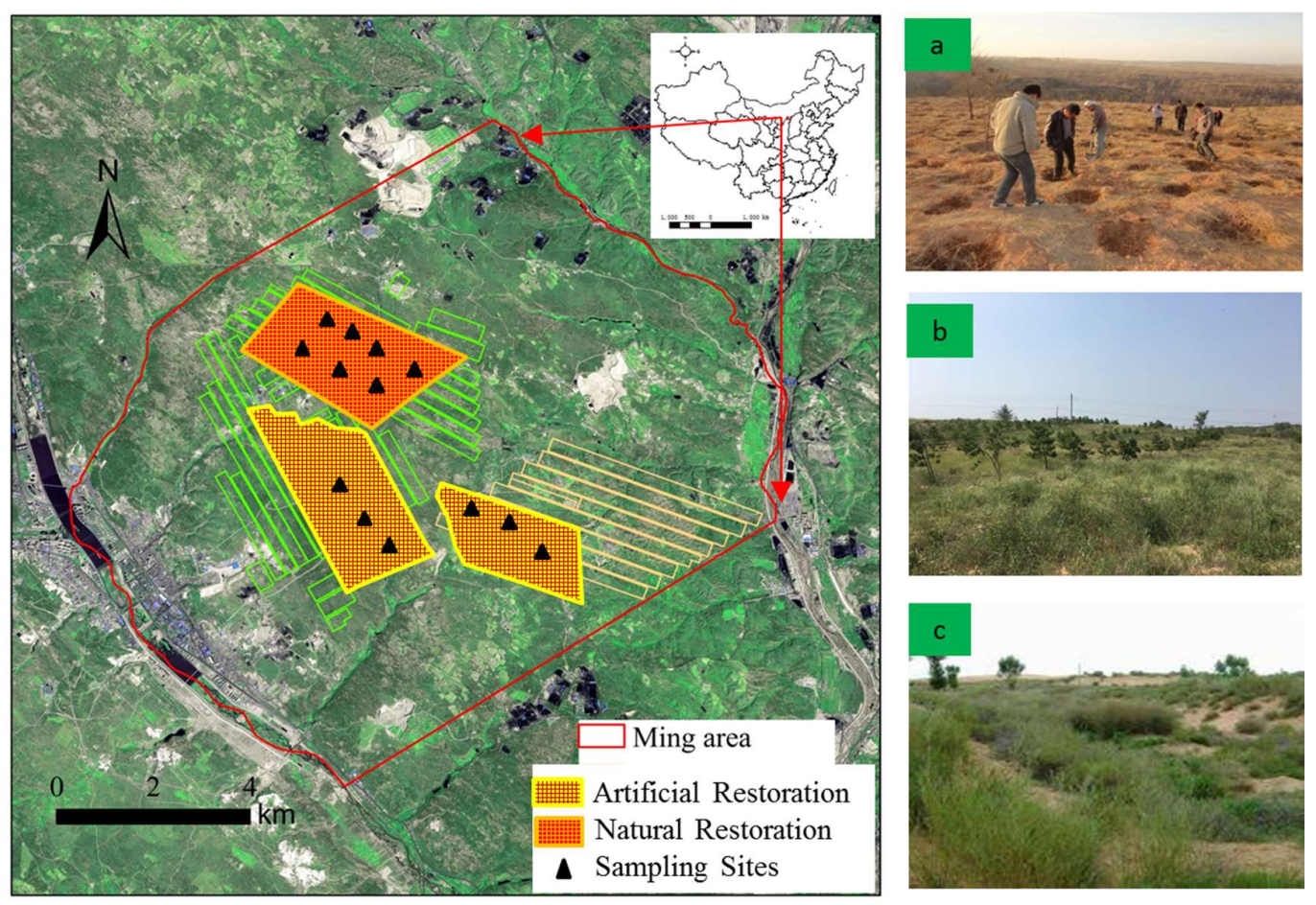

Fig. 1. The location of study site, the coal mining area was located in red box, light yellow mesh

surface represents the artificial restoration area, dark yellow mesh surface represents the natural

restoration area. (a Artificial construction in restoration area; $\mathbf{b}$ Artificial restoration of landforms;

c Natural restoration of landforms)

\subsection{Soil sampling}

There were total 13 representative plots $(10 \mathrm{~m} \times 10 \mathrm{~m})$ distributed in two study areas, 7 plots for AR and 6 plots for NR. 5 small quadrats $(1 \mathrm{~m} \times 1 \mathrm{~m})$ were randomly arranged in each plot.

Sites AR and NR were the earliest sites restored in 1997, and have been subjected to the longest succession period among all sites. In order to obtain the initial soil properties data, soil moisture content, nitrogen and phosphorus, etc. were collected in selected sites. According to Chen et al. (2017) study, these essential soil properties may affect microbial communities similar to all sites.

Soil sampling time was in July 2017, representing the summer of the study area. The position of 
sampling sites was recorded by a portable global position system (GPS) (eTrex Venture, Garmin, Lenexa, KS, USA). Removing litter from the soil surface before sampling, and then soil samples were collected at a depth between 5 and $30 \mathrm{~cm}$, with three replicates at each small quadrat (Chen et al., 2017). If the soil has been turned, it should be a little deeper to avoid microbial contamination in the air. In addition, soil samples were collected, mixed and preserved in an aseptic bag (about $50 \mathrm{~g}$ ). Samples were stored in prepared ice boxes, transferred to the laboratory within two hours, and stored at $-20^{\circ} \mathrm{C}$ prior to microbial species testing. The samples collected from AR were labeled as AR_1, AR_2, AR_3, AR_4, AR_5 AR_6and AR_7, while these from NR were labeled as NR_1, NR_2, NR_3, NR_4, NR_5 and NR_6.

\subsection{Soil microbial community analysis}

(1) DNA extraction and purification

The soil samples in each aseptic bag was mixed well and homogenized. Genomic DNA was extracted from 0.5g soil using E.Z.N.A Soil DNA Kit (Life Technologies, Carlsbad, USA).. DNA concentration and purity were detected by NanoDrop -2000 micro spectrophotometer, and Using $1 \%$ agarose gel to detect DNA integrity. The qualified samples were kept in a $-20{ }^{\circ} \mathrm{C}$ refrigerator.

(2) Microbial 16S rRNA gene amplification

In order to analyze the differences of soil microbial communities in two plots, the bacterial 16S rRNA gene was amplified using polymerase chain reaction (PCR). After purified DNA was used as a template, $16 \mathrm{~S}$ rRNA was amplified with a universal bacterial forward primer 515F (5' GTGCCAGCMGCCGCGG-3') and reverse primer R907 (5'-CCGTCAATTCMTTTRAGTTT-3'). The primers were provided by Shanghai m-image bio Pharmaceutical Technology Co. The PCR 
reaction was carried out in the ABI GeneAmp type 9700 instruments (Applied, Biosystems, Foster, City, USA).

(3) High-throughput sequencing and bioinformatics analysis

PCR products, purified and quality - tested, were subjected to high-throughput sequencing in Illumina Miseq PE250 platform of Shanghai M-image bio Pharmaceutical Technology Co. The PE reads obtained by Miseq sequencing was first spliced according to the overlap relationship, and the quality of the sequence is controlled and filtered at the same time. OTU clustering analysis and species taxonomic analysis were conducted after distinguishing samples, and diversity index analysis and OTU cluster analysis could be carried out based on OTU.

\subsection{Soil physical and chemical properties analyses}

Samples, sieved through $0.2 \mathrm{~mm}$ mesh, should be air - dried naturally for at least one week before determination of soil properties, and stored in a refrigerator with $4^{\circ} \mathrm{C}$ prior to further analyses. Soil moisture content (MC) was measured using a ML3X soil moisture tester (Delta-T, Inc., UK) (three replicates). Soil bulk density (BD) was measured using cutting ring method. Soil $\mathrm{pH}$ and electrical conductivity (EC) were measured using a pH meter (Origin Research Inc.) and an electrical conductivity meter (LF 330/SET, WTW), respectively. Soil organic matter (OM) was measured using the method described in (Sparks et al., 2009) and (Chen et al., 2017).

The determination of soil chemical properties, such as total nitrogen (TN), phosphorus (TP), potassium $(\mathrm{TK})$, copper $(\mathrm{Cu})$, iron $(\mathrm{Fe})$, manganese $(\mathrm{Mn})$, lead $(\mathrm{Pb})$ and zinc $(\mathrm{Zn})$, refers to the methods described in (Chen et al., 2017; Sparks et al., 1996). For TN and TP, $0.5 \mathrm{~g}$ of sieved soil was digested using the Kjeldahl method and the semi-micro Kjeldahl method, and followed by the 
Molybdenum-blue method and the Indophenol-blue method, respectively. Extractable $\mathrm{N}$ and $\mathrm{P}$ were determined using the Molybdenum-blue method and the Indophenol-blue method, respectively (Chen et al., 2017). For total $\mathrm{Cu}, \mathrm{Fe}, \mathrm{Mn}, \mathrm{Pb}, \mathrm{Zn}$ and $\mathrm{K}, 0.5 \mathrm{~g}$ of sieved soil was digested concentrated hydrofluoric acid and nitrite acid, and analyzed using atomic absorption spectrophotometry analysis (SpectrAA 220FS, Varian). For extractable $\mathrm{Cu}, \mathrm{Fe}, \mathrm{Mn}, \mathrm{Pb}, \mathrm{Zn}$ and $\mathrm{K}$, $0.5 \mathrm{~g}$ of sieved soil was analyzed using atomic absorption spectrophotometry analysis (SpectrAA 220FS, Varian) (Chen et al., 2017).

\subsection{Plant properties analyses}

Plant survey was conducted in quadrat of each plot, which was described in 2.2 detailedly. All the plants in the quadrat were record and identified at species level. Species identification followed Chang and Liu (2010). Parameters of plant community characteristics, such as relative canopy cover (RC), important value (IV), relative density (RDe), relative dominance (RDo), and relative frequency (RF) were calculated for plant communities within quadrats. In order to compare similarity of the species composition in different restoration plots, Jaccard index $(J I)$, Dice index $(D I)$ and Ochiai index $(O I)$ were also calculated. The calculation of these parameters was detailedly described in article (Hazarika, 2013; Song, 2008).

Vegetation coverage was also calculated in two study sites. In this paper, Landsat satellite remote sensing images from 2003 to 2017 were selected. Image data (path 127/row 33) was downloaded from the U.S. Geological Survey (USGS) data platform. Detailed information on remote sensing images was described in Zhang et al., 2015. The vegetation cover index was calculated using the methods described by Sun et al., 2016. 


\subsection{Data analysis}

The data of soil properties was summarized using mean values. And that of plant diversity and richness was summarized using No. of individual, RC, RDe, RDo, RF and IV. Data analysis was carried out using Microsoft Excel (Microsoft Inc., USA) and SPSS 19.0 software package for Windows. The calculation and statistics of NDVI and vegetation cover are carried out in ENVI (The Environment for Visualizing Images) software (Exelis Visual Information Solutions Co., USA). Graphical visualization was carried out in GIS software (ArcGIS, version 10.1) (Environmental Systems Research Institute, Inc., USA). A similarity matrix was constructed and visualized using hierarchical cluster analysis. Analysis of similarity was obtained to analyze the similarity of soil microbial community in two different sampling sites. $J I, D I$, and $O I$ for the coefficient of similarity of plant species in two different sampling sites were calculated (Carriço et al., 2005; Legendre and Legendre, 1998). Canonical correspondence analysis (CCA, unimodal response function assumed) was conducted using Canoco (version 4.5) (Scasta et al., 2012). The soil variables included in the CCA were selected by judging the variance inflation factors (VIF) which were calculated to detect the multicollinearity during regression analysis (Hyvärinen and Kauppi, 1992; Ramette, 2007).

\section{Results}

\subsection{Soil properties}

Significant differences $(p<0.05)$ among AR and NR were observed in soil properties, such as BD, TP and extractable N. Significant differences $(p<0.01)$ among AR and NR were observed in soil properties including $\mathrm{EC}, \mathrm{MC}$, TOC, $\mathrm{OM}$, extractable $\mathrm{P}$, extractable $\mathrm{K}$, total $\mathrm{Cu}$, extractable $\mathrm{Cu}$, 
extractable $\mathrm{Pb}$, total $\mathrm{Zn}$ and extractable $\mathrm{Zn}$ (Table 1). Lower $\mathrm{pH}, \mathrm{BD}, \mathrm{TN}$, total $\mathrm{Cu}$, extractable $\mathrm{Cu}$ and total $\mathrm{Pb}$ were observed in soil from $\mathrm{AR}$, whereas there was higher $\mathrm{EC}, \mathrm{MC}, \mathrm{OM}$, extractable $\mathrm{N}$, total $\mathrm{P}$, extractable $\mathrm{P}$, total $\mathrm{K}$, extractable $\mathrm{K}$, total $\mathrm{Zn}$ and extractable $\mathrm{Zn}$, when compared with soil from NR.

Soil $\mathrm{MC}, \mathrm{pH}$ value and $\mathrm{OM}$ were important factors to control microbial community (Van Horn et al., 2013). Soil MC was positively related to microbial activity, and increasing water content can effectively improve microbial activity (Fu et al., 2009; Sha et al., 2013). The MC collected from AR was 10.59\%, compared with 7.43\% from NR (Table 1). Compared with other soil properties, such as latitude, temperature, organic carbon, $\mathrm{C}: \mathrm{N}$ ratio, soil $\mathrm{pH}$ was the best predictor of soil bacterial community composition (Feng et al., 2014). The soil pH in AR was 8.34, compared with 8.92 in NR. The soil microbial diversity was highest when the $\mathrm{pH}$ value was about 7 (Chen et al., 2017). Organic matter, including plant residues, animal residues and root exudates, is the major source of microbial consumption (Parton et al., 2015). In alkaline soil, there was a negative correlation between organic matter content and $\mathrm{pH}$ value (Dai et al., 2009). The OM of the soil from AR (8.75\%) was high than from NR (4.72\%). Higher soil MC, OM and lower pH value were mainly associated with higher vegetation coverage in AR. On the one hand, the higher vegetation coverage was beneficial to soil water conservation, on the other hand, more broken branches and fallen leaves were produced on the ground surface, and the organic matter content was higher, which is beneficial to the reduction of $\mathrm{pH}$ value.

Table 1 Soil properties of the samples collected from the artificial restoration area (AR), natural restoration area $(\mathrm{NR})$. 


\begin{tabular}{|c|c|c|}
\hline \multirow{2}{*}{ Soil properties } & \multicolumn{2}{|c|}{ Sites } \\
\hline & $\mathrm{AR}$ & NR \\
\hline $\mathrm{pH}$ & $8.34 \pm 0.57$ & $8.92 \pm 0.68$ \\
\hline $\mathrm{EC}\left(\mathrm{ms} \mathrm{cm}^{-1}\right)^{* *}$ & $167 \pm 26.42$ & $134 \pm 22.57$ \\
\hline $\mathrm{BD}\left(\mathrm{g} \mathrm{cm}^{-3}\right)^{*}$ & $1.49 \pm 0.13$ & $1.60 \pm 0.11$ \\
\hline $\operatorname{MC}(\%)^{* *}$ & $10.59 \pm 1.73$ & $7.43 \pm 1.54$ \\
\hline TOC $(\%)^{* *}$ & $16.89 \pm 4.21$ & $9.54 \pm 3.74$ \\
\hline $\mathrm{OM}(\%)^{* *}$ & $8.75 \pm 4.24$ & $4.72 \pm 2.04$ \\
\hline Total $\mathrm{N}\left(\mathrm{g} \mathrm{kg}^{-1}\right)$ & $0.42 \pm 0.08$ & $0.46 \pm 0.19$ \\
\hline Extractable $\mathrm{N}\left(\mathrm{g} \mathrm{kg}^{-1}\right)^{*}$ & $0.017 \pm 0.001$ & $0.016 \pm 0.001$ \\
\hline Total $\mathrm{P}\left(\mathrm{g} \mathrm{kg}^{-1}\right)^{*}$ & $0.31 \pm 0.08$ & $0.27 \pm 0.06$ \\
\hline Extractable $\mathrm{P}\left(\mathrm{g} \mathrm{kg}^{-1}\right)^{* *}$ & $0.035 \pm 0.004$ & $0.011 \pm 0.006$ \\
\hline Total $\mathrm{K}\left(\mathrm{g} \mathrm{kg}^{-1}\right)$ & $15.49 \pm 1.39$ & $15.37 \pm 2.33$ \\
\hline Extractable $\mathrm{K}\left(\mathrm{g} \mathrm{kg}^{-1}\right)^{* *}$ & $0.011 \pm 0.004$ & $0.005 \pm 0.001$ \\
\hline Total $\mathrm{Cu}\left(\mathrm{mg} \mathrm{kg}^{-1}\right)^{* *}$ & $19.61 \pm 3.54$ & $26.22 \pm 4.38$ \\
\hline Extractable $\mathrm{Cu}\left(\mathrm{mg} \mathrm{kg}^{-1}\right)^{* *}$ & $6.31 \pm 1.22$ & $9.44 \pm 2.29$ \\
\hline Total $\mathrm{Pb}\left(\mathrm{mg} \mathrm{kg}^{-1}\right)$ & $13.26 \pm 2.91$ & $18.93 \pm 4.25$ \\
\hline Extractable $\mathrm{Pb}\left(\mathrm{mg} \mathrm{kg}^{-1}\right)^{* *}$ & $6.92 \pm 1.21$ & $4.54 \pm 1.71$ \\
\hline Total $\mathrm{Zn}\left(\mathrm{mg} \mathrm{kg}^{-1}\right)^{* *}$ & $57.68 \pm 4.89$ & $30.81 \pm 4.81$ \\
\hline Extractable $\mathrm{Zn}\left(\mathrm{mg} \mathrm{kg}^{-1}\right)^{* *}$ & $18.41 \pm 2.34$ & $12.67 \pm 3.41$ \\
\hline
\end{tabular}

Soil properties with significant difference between the two different areas are highlighted with "*", $(p<0.05)$ and "***, $(p<0.01)$. All tests were conducted at the significance level of 0.05 . Data are mean \pm S.D. (for $A R, n=7$; for $N R, n=6$ ).

\subsection{Plant properties}

Plant diversity and richness of two different areas were counted in Table 2. AR plots with a total of 17 plant species, including ecological restoration plants: Amygdalus Pedunculata Pall, Cerasus Humilis, Pinus, Hippophae Rhamnoides Linn and Xanthoceras Sorbifolium Bunge. There were 14 plant species in NR. The No. of plant individual in AR and NR was 1075 and 1145, respectively. Compared with NR, there were more kinds and quantities of deciduous shrub included in the AR area, which was mainly related to the artificial implant restoration species. However, the vegetation was mainly composed of annual or perennial herbs in the NR. The 
relative canopy coverage $(\mathrm{RC})$ of vegetation in $\mathrm{AR}$ was higher, with a value of $74.12 \%$. The $\mathrm{RC}$ in NR was lower (63.94\%). The more plant species and higher RC also indicated good results had been achieved in artificial restoration in coal mining subsidence area.

The plant species recorded in AR and NR both contained native species (Table 2). Caragana Korshinskii, Artemisia Ordosica, Linum Stelleroides Planch, Populus, Heteropappus Hispidus Less, Achnatherum Splendens, Lespedeza Floribunda Bunge and Iris Tenuifolin Pall were native species recorded in both AR and NR. Lespedeza Floribunda Bunge (Rde: 13.99\%), Ephedra Sinica Stapf (Rde: 23.91\%), Achnatherum Splendens (Rde: 34.88\%) were the three dominant species in AR. Artemisia Ordosica (Rde: 10.36\%), Achnatherum Splendens (Rde: 20.87\%), Ephedra Sinica Stapf (Rde: 23.10\%) and Chenopodium Album L. (Rde: 10.22\%) were the four dominant species in NR. There were 10 of the same plant species in AR and NR. In order to compare similarity of the species composition in different restoration plots, $J I, D I$ and $O I$ were also calculated (data not shown). The $J I, D I$ and $O I$ of similarity of the plant communities of AR - NR were $0.24,0.39$, and 0.35 , respectively. The low similarity indicated that there are differences in plant communities in two regions. Restoration species (mostly exotic) were used for restoration in $\mathrm{AR}$, as these species can grow faster, better, and be more adapted to harsh environments (Wong et al., 2016; Chen et al., 2017). Eventually, these species subsequently competed with native species in this stressful environment (mainly drought), resulting in a relatively low diversity and density of native species (Table 2). It was demonstrated that Amygdalus Pedunculata Pall, Cerasus Humilis, Xanthoceras Sorbifolium Bunge, Hippophae Rhamnoides Linn had good drought resistance, and they were good soil and water conservation 
species in sandy land (Xiaofen et al., 2013; Guo et al., 2013; Liu, 2011). However, planting large amounts of these plants may reduce species diversity later and may also affect the food web (Chen et al., 2017).

Table 2 Plant properties in AR and NR.

\begin{tabular}{|c|c|c|c|c|c|c|}
\hline \multirow{2}{*}{ Plant species } & \multirow{2}{*}{$\begin{array}{l}\text { No. of } \\
\text { individual }\end{array}$} & \multirow{2}{*}{$\frac{\mathrm{RC}}{\left(\mathrm{m}^{2}\right)}$} & \multirow{2}{*}{$\begin{array}{l}\text { Rde } \\
(\%)\end{array}$} & \multirow{2}{*}{$\begin{array}{l}\text { Rdo } \\
(\%)\end{array}$} & \multirow{2}{*}{$\begin{array}{l}\mathrm{RF} \\
(\%)\end{array}$} & \multirow{2}{*}{$\frac{\text { IV }}{(\%)}$} \\
\hline & & & & & & \\
\hline \multicolumn{7}{|l|}{$\mathbf{A R}$} \\
\hline Amygdalus Pedunculata Pall ${ }^{\text {a }}$ & 14 & 14.60 & 1.30 & 19.70 & 1.30 & 7.43 \\
\hline Cerasus Humilis a & 9 & 4.50 & 0.87 & 6.07 & 0.87 & 2.60 \\
\hline Pinus $^{\mathrm{b}}$ & 8 & 6.40 & 0.74 & 8.63 & 0.74 & 3.37 \\
\hline Artemisia Ordosica ${ }^{\text {a }}$ & 24 & 6.30 & 2.26 & 8.50 & 2.26 & 4.34 \\
\hline Xanthoceras Sorbifolium Bunge ${ }^{\text {a }}$ & 12 & 5.10 & 1.12 & 6.88 & 1.12 & 3.04 \\
\hline Caragana Korshinskii ${ }^{\text {a }}$ & 9 & 9.70 & 0.86 & 13.09 & 0.86 & 4.94 \\
\hline Lespedeza Floribunda Bunge ${ }^{\text {a }}$ & 150 & 4.00 & 13.99 & 5.40 & 13.99 & 11.13 \\
\hline Populus L. ${ }^{\mathrm{b}}$ & 22 & 6.80 & 2.00 & 9.17 & 2.00 & 4.39 \\
\hline Salix Cheilophila ${ }^{\text {a }}$ & 2 & 4.00 & 0.19 & 5.40 & 0.19 & 1.92 \\
\hline Hippophae Rhamnoides Linn ${ }^{\text {a }}$ & 26 & 4.50 & 2.42 & 6.07 & 2.42 & 3.64 \\
\hline Heteropappus Hispidus Less ${ }^{\mathrm{c}}$ & 22 & 0.40 & 2.05 & 0.54 & 2.05 & 1.54 \\
\hline Medicago Sativa L. ${ }^{\mathrm{d}}$ & 79 & 3.80 & 7.37 & 5.13 & 7.37 & 6.62 \\
\hline Ephedra Sinica Stapf ${ }^{\mathrm{d}}$ & 257 & 0.94 & 23.91 & 1.27 & 23.91 & 16.36 \\
\hline Achnatherum Splendens ${ }^{\mathrm{d}}$ & 375 & 0.90 & 34.88 & 1.21 & 34.88 & 23.66 \\
\hline Cymbaria Mongolica Maxim $^{\mathrm{d}}$ & 2 & 0.90 & 0.19 & 1.21 & 0.19 & 0.53 \\
\hline Euphorbia Esula Linn ${ }^{\mathrm{d}}$ & 1 & 0.90 & 0.09 & 1.21 & 0.09 & 0.47 \\
\hline Iris Tenuifolin Pall ${ }^{\mathrm{d}}$ & 62 & 0.38 & 5.80 & 0.51 & 5.80 & 4.04 \\
\hline Total 17 species & 1075 & 74.12 & & & & \\
\hline \multicolumn{7}{|l|}{ NR } \\
\hline Caragana Korshinskii ${ }^{\text {a }}$ & 7 & 7.5 & 0.59 & 12.93 & 0.59 & 4.71 \\
\hline Artemisia Ordosica $^{\text {a }}$ & 119 & 28.6 & 10.36 & 53.60 & 10.36 & 24.78 \\
\hline Linum Stelleroides Planch ${ }^{\mathrm{a}}$ & 4 & 6.2 & 0.37 & 9.75 & 0.37 & 3.50 \\
\hline Populus L. ${ }^{\mathrm{b}}$ & 3 & 6.4 & 0.23 & 10.12 & 0.23 & 3.52 \\
\hline Lespedeza Floribunda Bunge ${ }^{\text {a }}$ & 58 & 1.9 & 5.10 & 2.44 & 5.10 & 4.21 \\
\hline Allium Mongolicum Regel ${ }^{\mathrm{d}}$ & 26 & 0.1 & 2.27 & 0.19 & 2.27 & 1.58 \\
\hline Medicago Sativa L. ${ }^{\mathrm{d}}$ & 60 & 6.9 & 5.26 & 5.43 & 5.26 & 5.32 \\
\hline Chenopodium Album L. ${ }^{\mathrm{c}}$ & 117 & 0.5 & 10.22 & 0.94 & 10.22 & 7.12 \\
\hline Iris Tenuifolin Pall ${ }^{\mathrm{d}}$ & 82 & 0.55 & 7.14 & 1.03 & 7.14 & 5.10 \\
\hline Ephedra Sinica Stapf ${ }^{\mathrm{d}}$ & 265 & 1.98 & 23.10 & 1.12 & 23.10 & 15.78 \\
\hline Heteropappus Hispidus Less ${ }^{\text {c }}$ & 47 & 1.04 & 4.12 & 0.07 & 4.12 & 2.77 \\
\hline Achnatherum Splendens ${ }^{\mathrm{d}}$ & 239 & 1.65 & 20.87 & 1.22 & 20.87 & 14.32 \\
\hline
\end{tabular}




\begin{tabular}{lcccccc} 
Thesium Chinense Turcz $^{\mathrm{d}}$ & 50 & 0.2 & 4.37 & 0.37 & 4.37 & 3.04 \\
Murdannia Nudiflora Brenan $^{\mathrm{d}}$ & 69 & 0.42 & 6.03 & 0.79 & 6.03 & 4.28 \\
Total 14 species & 1145 & 63.94 & & & & \\
\hline
\end{tabular}

Species names in bold are restoration species.

${ }^{\mathrm{a}}$ Deciduous shrub; ${ }^{\mathrm{b}}$ Deciduous trees; ${ }^{\mathrm{c}}$ Annual herb; ${ }^{\mathrm{d}}$ Perennial herb.

The time-series remotely sensed imagery in Landsat series provided good data sources for dynamic analysis of vegetation coverage in restoration areas (Zhang et al., 2015). According to formula (1) and (2), vegetation coverage in the restoration area was calculated (Fig. 2). Because the vegetation in the study area grew best from August to September, this paper listed vegetation cover maps in August or September from 2003 to 2017 (some years were not listed, because the amount of cloud cover was too high for remote sensing images in this month, so it was not suitable for vegetation cover calculation). On the whole from Fig. 2, until August 2010, the area of dark green increased slowly, indicating that vegetation coverage tended to be better in both AR and NR areas. After August 2010, the change of vegetation coverage seems small or not obvious. In order to further analyze the changes of vegetation coverage in AR and NR areas, it is necessary to make a statistical analysis of regional vegetation coverage from 2003 to 2017 (Fig. 3). The vegetation coverage in AR was lower than that in NR from 2003 to 2006. After 2006, the vegetation coverage in AR was higher than that in NR. Compared with the NR, the vegetation coverage in the AR increased with an average percentage of $7.15 \%$. In 2003, the vegetation coverage in AR and NR was 51.34\% and 56.18\%. Until September 2017, the vegetation coverage in AR and NR was $73.06 \%$ and $67.57 \%$. Vegetation coverage increased by $43.36 \%$ in the AR area compared with early recovery, while in the NR area only $20.28 \%$ increased. Therefore, under artificial intervention, the vegetation coverage in coal mining subsidence area has been 
significantly improved, and the vegetation restoration in the damaged mining area in this area has got some achievements. Notably, in both AR and NR areas in August 2010, vegetation coverage was relatively low, which possibly related to climatic conditions at that time, such as rainfall (Fensham et al., 2005).

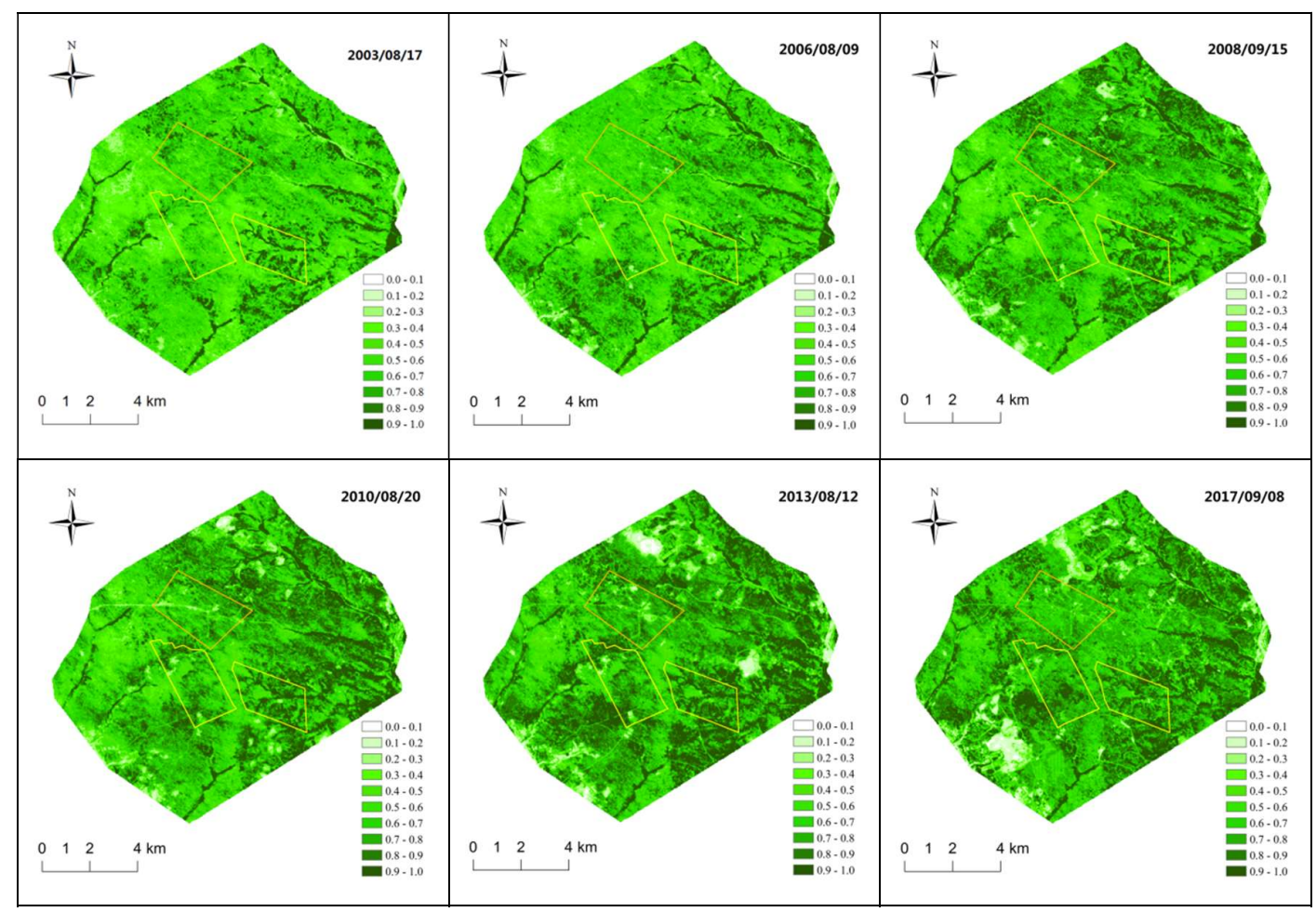

Fig. 2. Change map of vegetation coverage in two restoration sites. The light yellow area is the artificial restoration area, and the deep yellow area is the natural restoration area. The deeper the green, the higher the vegetation coverage. 


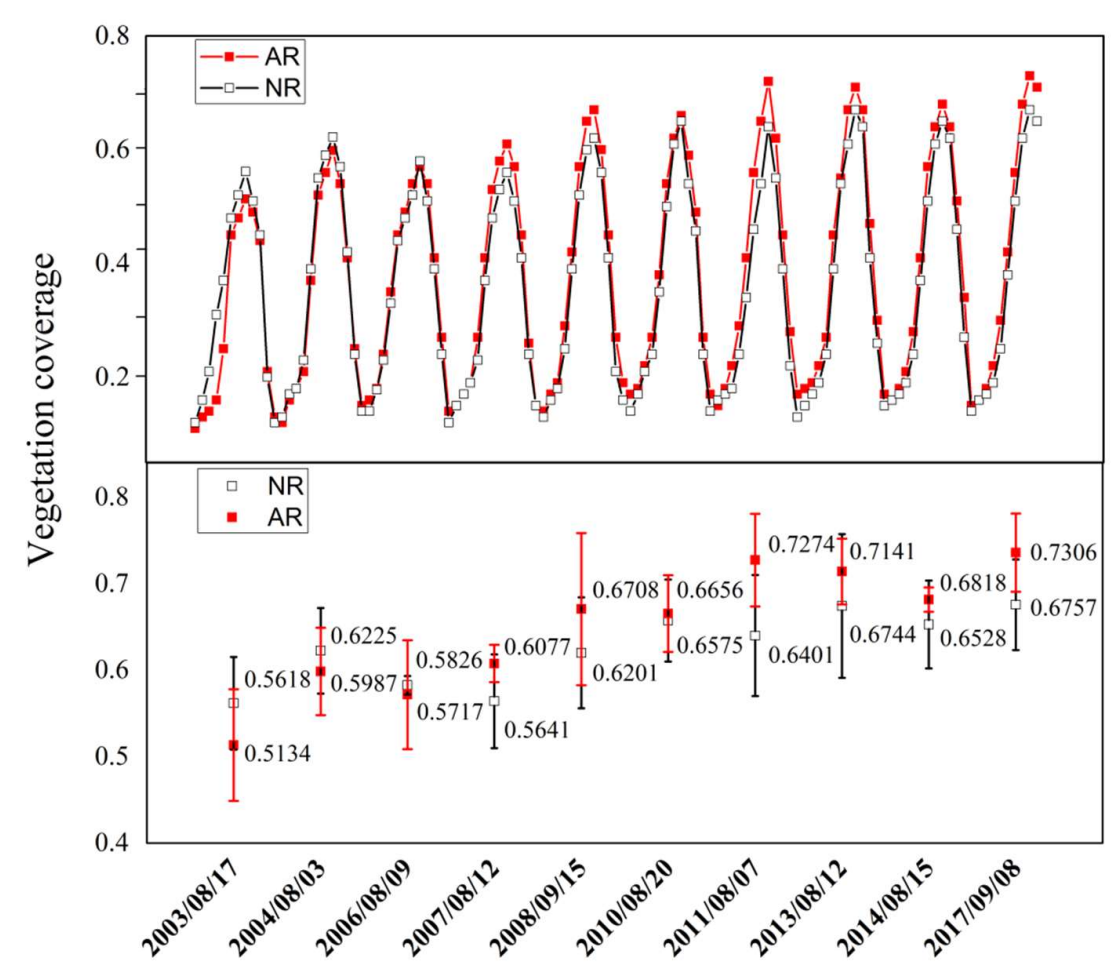

Fig. 3. Comparison of vegetation coverage for different years between the artificial restoration area $(\mathrm{AR})$ and the natural restoration area (NR).

\subsection{Soil microbial communities properties}

The major phyla composition derived from the soil collected at AR and NR was shown in Fig.4. Hierarchical cluster analysis comparing different soil microbial communities from different soil samples collected at AR and NR was shown in Fig.5. A total of 19 phyla were obtained after high throughput sequencing and cluster analysis of the bacterial 16S rRNA genes collected from 13 soil samples (Fig.4 and Fig.5). Among them, mainly included: Acidobacteria (16.27\%), Actinobacteria (11.60\%), Chloroflexi (14.51\%), Cyanobacteria (6.54\%), Planctomycetes (2.76\%), Proteobacteria $(4.21 \%)$, Nitrospirae $(11.93 \%)$. These phyla accounted for $67.82 \%$ of the total microbial count in all soil samples. Acidobacteria, Actinobacteria, Chloroflexi, Cyanobacteria, Planctomycetes, Proteobacteria and Nitrospirae were dominant in soil microbial community 
structure and dominant microbial groups in the soil of the study areas, which was consistent with many reports (Ren, 2017; Xu, 2011; Chen et al., 2017). This indicated that these floras had extensive adaptability to environment and played an important role in ecosystem. In addition, about $2.87 \%$ of all sequences were not assigned to any of the existing phyla, indicating the presence of non - recognized microbial resources in the region.

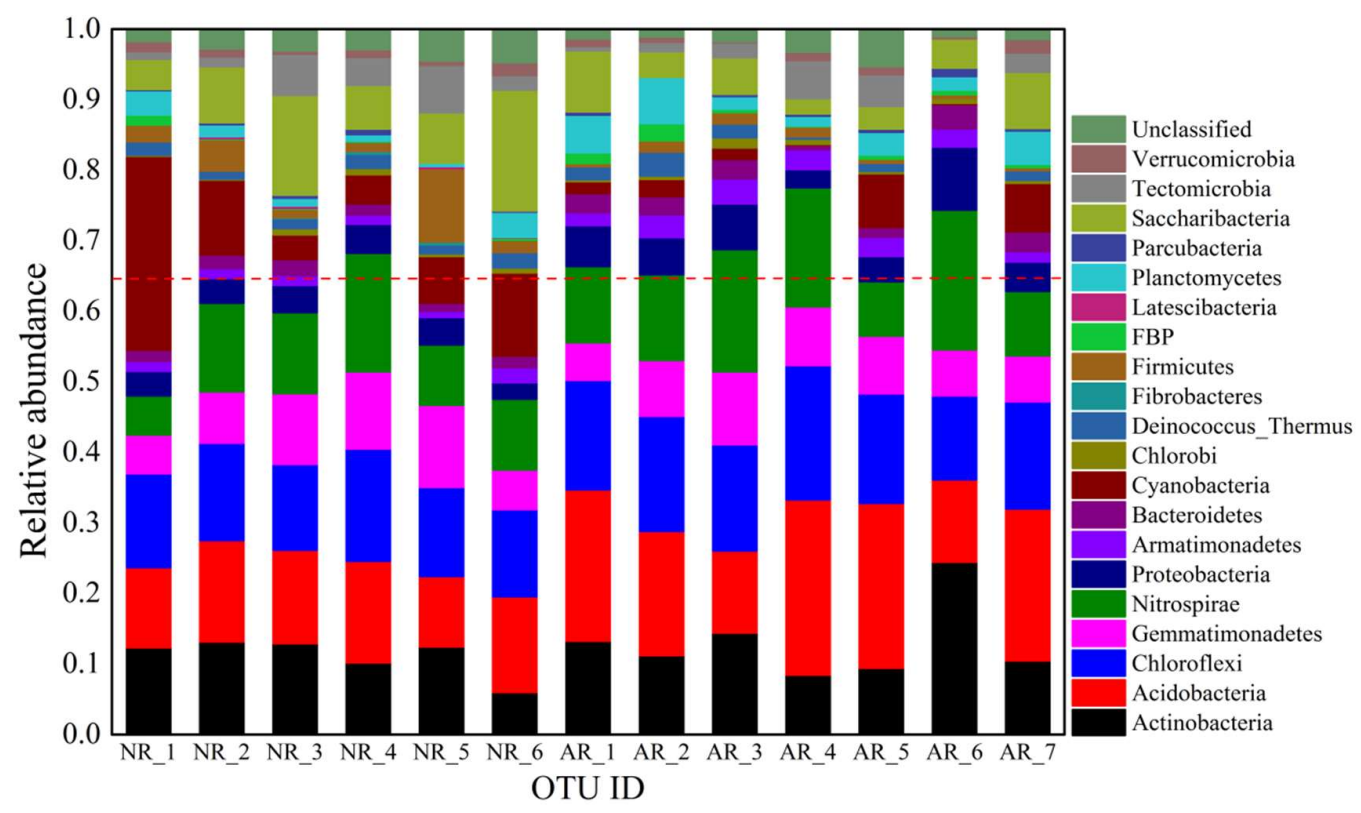

Fig. 4. The major phyla composition derived from the soil collected at AR and NR. Different colors represent different microbial phyla. The samples collected from AR were labeled as AR_1, AR_2, AR_3, AR_4, AR_5, AR_6 and AR_7, while the samples from NR were labeled as NR_1, NR_2, NR_3, NR_4, NR_5 and NR_6.

There were some differences in microbial community composition between different sampling sites. No Fibrobacteres and Latescibacteria were presented in the microbial community of NR relative to AR, although the relative abundance was low. Except Cyanobacteria, the mean relative abundance of Acidobacteria, Chloroflexi, Planctomycetes, Proteobacteria and Nitrospirae in AR was higher than in NR. This difference may be related to the soil environment and plant 
diversity and richness in different plots. At sites AR, 17 plant species, with canopy coverage of $74.12 \%$, were found in the plot, while 14 plant species and with canopy cover of $53.36 \%$ were recorded for NR. Probably the more plant species, the more broken branches and fallen leaves, the higher the soil organic matter content (Table 1), providing a more abundant source of energy for the growth of microbial (Parton et al., 2015). A different conclusion was drawn by Chen et al. (2017), showing that there was no clear relationship between plant diversity and soil microbial diversity. This may be related to plant canopy coverage in this study. According to the results of Zak et al. (2003), the biomass of microbial communities increased with the increase of plant diversity. The $\mathrm{pH}$ in $\mathrm{AR}(8.34 \pm 0.57)$ was lower than that in NR $(8.82 \pm 0.68)$. Based on previous findings, $\mathrm{pH}$ was a key factor controlling the structure of soil microbial communities (Chen et al., 2017), and pH values closer to 7 showed an increased phylotype diversity (Fierer and Jackson, 2006). In addition, according to Horn et al. (2013) research, soil microbial community diversity was also significantly related to soil $\mathrm{MC}, \mathrm{pH}$ and $\mathrm{OM}$.

The application of cluster analysis to construct different sampling areas of microbial community cluster heatmaps (Fig.5) and describe the similarities and differences between AR and NR of the soil microbial community structure. According to the clustering heatmaps showed that all samples of soil microbial community structure clustered into two clusters. AR_1, AR_2, AR_3, AR_4, AR_5 AR_6 and AR_7, were divided into a large cluster, NR_1, NR_2, NR_3, NR_4, NR_5 and NR_6 were divided into a large cluster. From Fig.5, the difference of bacterial community structure was mainly reflected in Acidobacteria, Actinobacteria, Chloroflexi, Cyanobacteria, Proteobacteria and Nitrospirae, this result was basically consistent with the 
analysis of relative abundance.

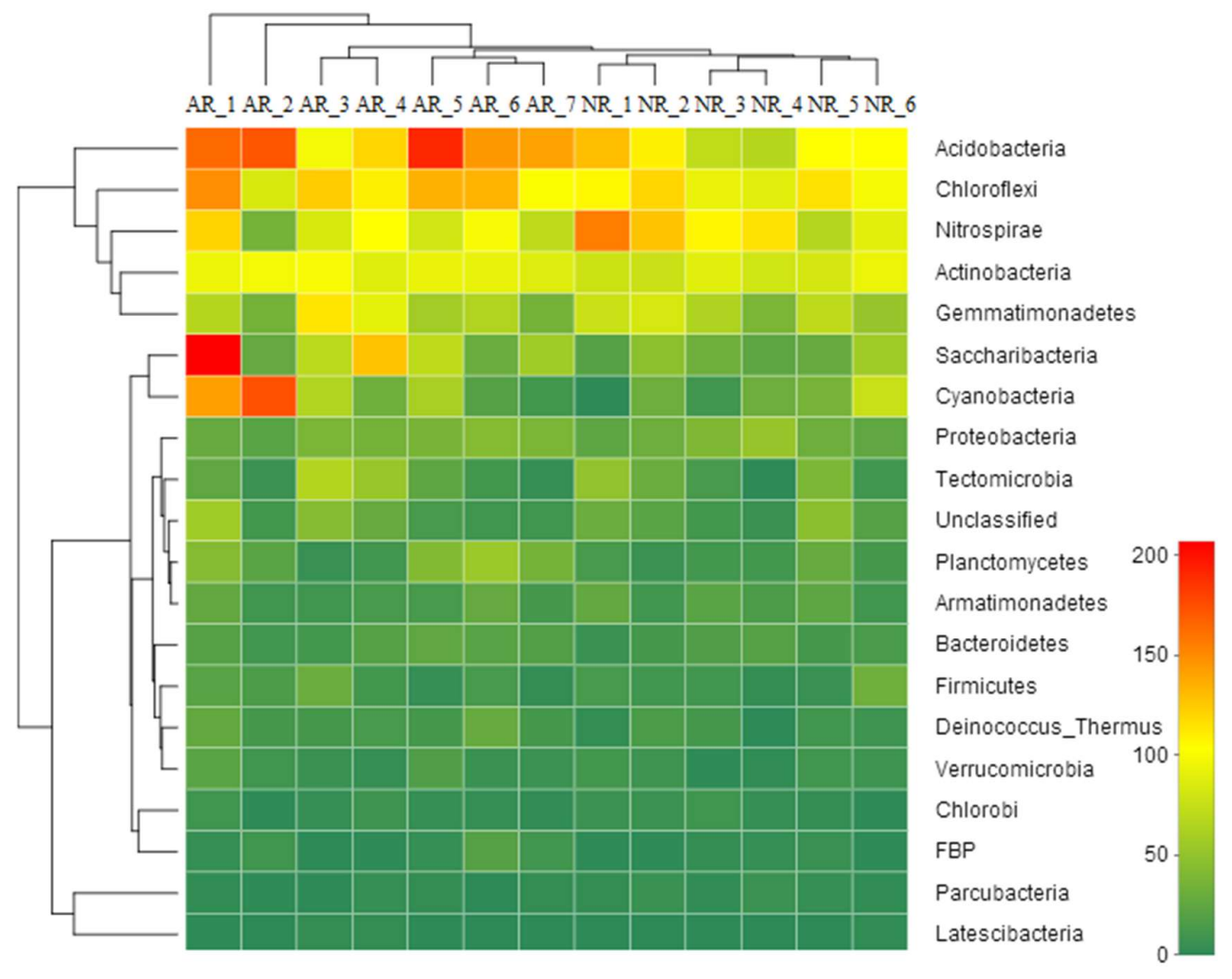

Fig. 5. Hierarchical cluster analysis comparing different soil microbial communities from different soil samples collected at AR and NR. The soils collected from AR were labeled as AR_1, AR_2, AR_3, AR_4, AR_5, AR_6and AR_7, while the soils from NR were labeled as NR_1, NR_2, NR_3, NR_4, NR_5 and NR_6.

\subsection{Potential driving factors on soil microbial communities}

A recent study attempted to investigate the factors controlling the soil microbial community structure and composition, and it was shown that these were significantly related with soil and vegetation properties (Cong et al., 2015). Nutrient elements, soil moisture, organic matter content and $\mathrm{pH}$ were different in different soil samples (Table 1). Different plant species and communities had different canopy coverage and rooting depth, and the quality and quantity of the broken 
branches and fallen leaves were also different (Garbeva et al., 2006; Chen et al., 2017; Cong et al., 2015; Zak et al., 2003). Soil MC was one of the important factors that affected the structure and composition of soil microbial (Sha et al., 2013; Fu et al., 2009). The higher RC in AR (74.12\%) (due to human intervention: vegetation reconstruction and rehabilitation) than NR (63.94\%) was one of the reasons that led to higher soil MC in $\mathrm{AR}(\mathrm{Table} 2)$. The number of soil microbial community decreased with the increase of bulk density (Wang et al., 2009). In the compacted soil with larger $\mathrm{BD}$, the decrease of its nutrient availability was one of the reasons for the change of soil microbial number and activity (Dick et al., 1988). Extractable $\mathrm{N}$ was the main nutrient in the process of ecosystem and TP and Extractable $\mathrm{P}$ were closely related to plant mycorrhizal symbiosis (Bonfante and Genre, 2010; Chen et al., 2017). According to the analysis in the former sections, OM, positively correlated with TOC, and $\mathrm{pH}$ were important soil factors for controlling microbial community and structure. Consequently, these soil properties were used for canonical corresponding analysis (CCA) to investigate potential influence factors on soil microbial communities (Fig.6). 


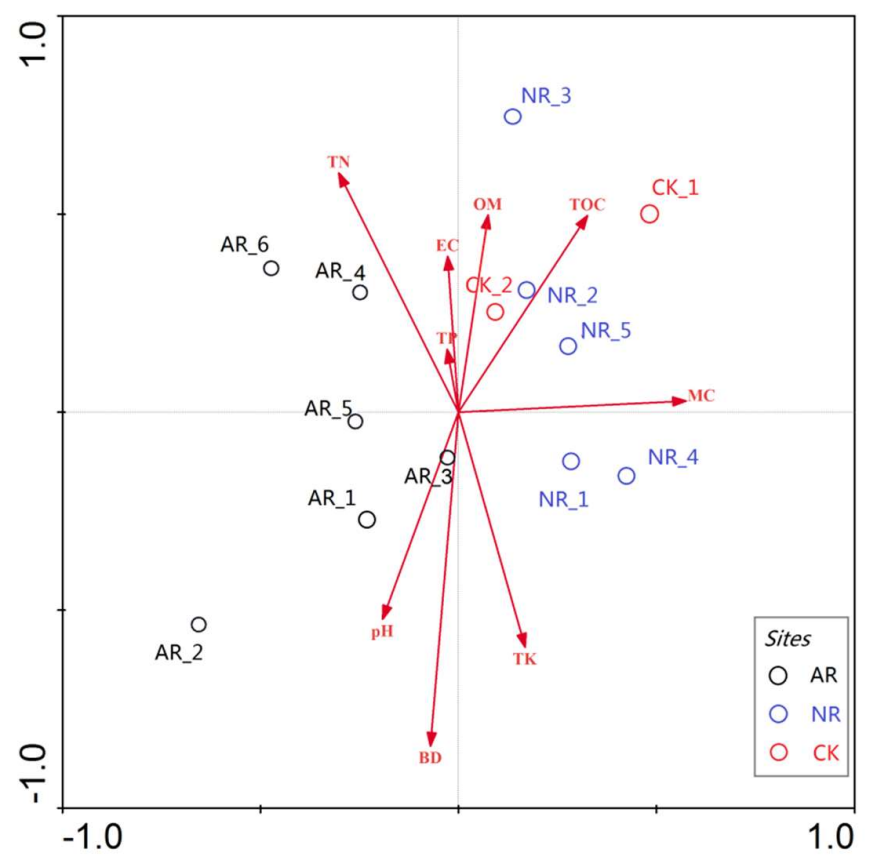

Fig. 6. Biplot of canonical correspondence analysis (CCA) for investigate potential influence factors on soil microbial communities. BD: bulk density; TP: total phosphorus; EP: extractable P; TN: total nitrogen; MC: moisture content; OM: organic matter; TOC: total organic carbon; EC: electrical conductivity.

As can be seen from Figure 6, soil samples, collected from different sites, were separated into two groups, one for AR and the other for NR (Fig.6). The potential soil factors influencing the soil microbial community mainly included $\mathrm{pH}, \mathrm{BD}$, and $\mathrm{TN}$ for bacteria in $\mathrm{AR}$; and $\mathrm{OM}, \mathrm{TOC}$, and MC for microbial in NR, based on corresponding arrows direction and magnitude in CCA (Fig.6), indicating that these were important soil factors for explicating the differences between the microbial communities from the two studied areas. Soil microbial communities and structure from NR were positively correlated with MC $(P<0.05$, Fig.6). Similar results were found by Cong et al. (2015), who showed that soil moisture content could influence soil microbial communities and control microbial activity across a range of environments, such as saline water, food, wood, 
biofilms, and soils. Another study also pointed out that low soil water content can cause decreasing of intracellular water potential and enzyme activity, and resulting in inhibition of microbial activity (Stark et al., 1995). Because the vegetation coverage and diversity in the AR were higher than those of NR, the soil MC of AR was expected to be higher than that of NR (Table 1). This involved the interaction between soil water content, soil microbial activity and vegetation characteristics. Undoubtedly, soil moisture was the most important limiting factor for the ecological restoration of semi - arid mining area on the Loess plateau (Liu et al., 2017). Soil microbial communities and structure from AR were negatively correlated with $\mathrm{pH}(P<0.05$, Fig.6). The soil was alkaline in the study area. The $\mathrm{pH}$ value in AR $(8.34 \pm 0.57)$ was lower than that in NR $(8.92 \pm 0.68)$. Studies pointed out that the $\mathrm{pH}$ closer to 7 showed an increased phylotype diversity (Chen et al., 2017; Fierer and Jackson, 2006).

In addition to soil $\mathrm{MC}, \mathrm{BD}$, total $\mathrm{N}$, and $\mathrm{TOC}$ were important factors affecting the microbial community (Chen et al., 2017; Bonfante and Genre, 2010). It was important to understand the effects of these properties on soil microbial diversity and abundance. The result of CCA showed that $\mathrm{OM}$ and TOC were positively correlated with bacterial communities $(P<0.05$, Fig.6). And the OM (8.75 \pm 4.24$)$ and TOC $(16.89 \pm 4.21)$ in AR were higher than those in in NR (4.72 \pm 2.04 and 9.54 \pm 3.74$)$. This was probably explained by plant species and their communities, for which canopy density, rooting depth and litter quality / quantity were different (Cong et al., 2015; Chen et al., 2017). Microorganisms were involved in the decomposition of plant litter, and changes in the quality and quantity of litter led to differences in soil TOC and OM (Sariyildiz and Anderson, 2003). Morever, soil $\mathrm{pH}$ affected soil OM by affecting the activity of microorganisms (Cheng et 
al., 2014). In our study, soil pH was lower in AR indicated that the higher the microbial activity, the more conducive to the decomposition of plant residual leaves, resulting in higher soil organic matter content (Table 1). This was one of the reasons for the different soil $\mathrm{N}$ content (Cong et al., 2015), although no distinct relationship between $\mathrm{N}$ content and plant cover and diversity in this study. In Fig.4, soil BD was negatively correlated with microbial communities $(P<0.05)$. The BD

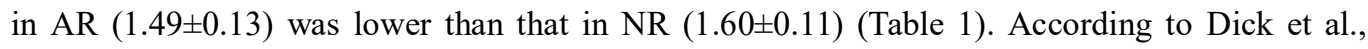
(1988), the greater soil BD, the greater soil compaction, and led to lower soil nutrient availability. However, the number and activity of soil microbial are closely related to the availability of soil nutrients.

Notably, the concentrations of total $\mathrm{Zn}$ and extractable $\mathrm{Zn}$ in soil from AR were significantly higher than those in NR (Table 1). Some studies had pointed out that the effect of the concentration of extractable $\mathrm{Zn}$ on the growth of microbial was greater than that of total $\mathrm{Zn}$ in soil (Saeki et al., 2002; Chen et al., 2017). Another study showed that extractable $\mathrm{Zn}$ began to affect microbial growth at concentrations of about $130 \mathrm{mg} \mathrm{kg}^{-1}$ (Diazravina and Baath, 1996). The concentration of extractable Zn both in $\mathrm{AR}\left(18.41 \pm 2.34 \mathrm{mg} \mathrm{kg}^{-1}\right)$ and $\mathrm{NR}\left(12.67 \pm 3.41 \mathrm{mg} \mathrm{kg}^{-1}\right)$ of this study was far less than $130 \mathrm{mg} \mathrm{kg}^{-1}$. Therefore, the concentration of $\mathrm{Zn}$ in soil had little influence on the soil microbial community in the study area.

The restoration of damaged ecosystems was a long process. And the ecosystem has always been in a dynamic process. In the early stage of coal mining in China, excessive attention to coal production led to severe damage to the mine environment (Wang, 2007), such as surface subsidence (Liu, 2017; Liu et al., 2013), soil erosion (Wang and Wang, 2001), vegetation damage 
(Li et al., 2006; Li et al., 2017), etc. With the proposing of the sustainable development strategy of the Chinese government and the improvement of the environmental awareness of the country, a series of measures are put forward for the ecological restoration of the mine, including re vegetation, and good results had been achieved (Zhang et al., 2007). It is very important to assess the similarity of soil - vegetation - microorganisms in the damaged mine restoration area and to study the influence of key soil properties on vegetation and microbial communities and overall development trend. This can provide theoretical guidance for more scientific ecological restoration in the damaged mining area. In this study, the soil microbial community diversity and structure were obtained by high throughput sequencing. However, it is still difficult to explain which bacteria play a decisive role in the ecological restoration of the mine.

\section{Conclusions}

The ecological restoration of Shendong mining area in 14 years has made some achievements. The bacterial community diversity and plant species in the artificial restoration area were higher than those in the natural area. This was mainly related to the introduction of ecological restoration species, which had stronger adaptability and drought tolerance than native species. After three years of artificial restoration, the vegetation coverage began to be higher than that in the natural restoration area, and the growth rate of vegetation coverage was significantly higher than that of the natural restoration area under the influence of artificial intervention. However, the soil and vegetation properties, microbial community diversity and structure in the ecological restoration area of coal mining subsidence are still somewhat different from the natural restoration ecosystem. The effects of restoring plant species on local plants (which are competing with each other) also 
need to be recognized. Soil factors, such as $\mathrm{pH}, \mathrm{OM}, \mathrm{TOC}, \mathrm{BD}, \mathrm{MC}$, and $\mathrm{N}$ have a greater impact on microbial community structure and diversity. The artificial intervention speeds up the recovery of damaged mines. Further studies will focus on which kinds of microbial have important impacts on ecological restoration in the mining area and the interaction among the plant - soil - microbial in the mining area.

\section{Acknowledgements}

The research was supported by the Fundamental Research Funds for the Central Universities (No. 2018BSCXC24); Postgraduate Research \& Practice Innovation Program of Jiangsu Province (No. KYCX18_1951)

\section{Reference}

Auestad, I., Rydgren, K., and Austad, I., 2016. Near - natural methods promote restoration of species - rich grassland vegetation - revisiting a road verge trial after 9 years. Restoration Ecology.24, 381-389.

Avera, B. N., Strahm, B. D., Burger, J. A., and Zipper, C. E., 2015. Development of ecosystem structure and function on reforested surface-mined lands in the Central Appalachian Coal Basin of the United States. New Forests. 46, 683-702.

Bi, Y., and Wu, F., 2006. Effects of mycorhiza on ecological restoration of solid wastes from coal mine and their nutritional dynamics. Transactions of the Chinese Society of Agricultural Engineering. 22, 147-152.

Bian, Z., Lei, S., Liu, H., and Deng, K., 2016. The process and countermeasures for ecological damage and restoration in coal mining area with super-size mining face at aeolian sandy site. 
Journal of Mining and Safety Engineering .2, 305-310.

Bian, Z. F., 2013. Countermeasures for sustainable development of ecological restoration of coal mines in contiguous area of Shanxi, Shaanxi and Mongolia. Forum on land reclamation and ecological restoration in China Mining Area.

Bonfante, P., and Genre, A., 2010. Mechanisms underlying beneficial plant-fungus interactions in mycorrhizal symbiosis. Nature Communications. 1, 48.

Carriço, J. A., Pinto, F. R., Simas, C., Nunes, S., Sousa, N. G., Frazão, N., Lencastre, H. D., and Almeida, J. S., 2005. Assessment of band-Based similarity coefficients for automatic type and subtype classification of microbial isolates analyzed by pulsed-field gel electrophoresis. Journal of Clinical Microbiology. 43, 5483.

Chazdon, R. L., 2008. Beyond Deforestation: Restoring forests and ecosystem services on degraded lands. Science. 320, 1458-1460.

Chang, H. J. and Liu, X. J., 2010. Common greening plants in Northwest Chin, Gansu science and Technology Press.

Chen, X. W., Wong, J. T., Leung, A. O., Ng, C. W., and Wong, M. H., 2017. Comparison of plant and bacterial communities between a subtropical landfill topsoil $15 y$ years after restoration and a natural area. Waste Management. 63, 49-57.

Cheng, L. S., Zhang, J. C., Lu, Q., Si, D. Y., and Zhuo, W. J., 2014. Effects of continuous planting of poplars on soil biological activity and nutrients. Journal of Nanjing Forestry University. 5, $85-90$.

Cong, J., Yang, Y., Liu, X., Lu, H., Liu, X., Zhou, J., Li, D., Yin, H., Ding, J., and Zhang, Y., 
2015. Analyses of soil microbial community compositions and functional genes reveal potential consequences of natural forest succession. Scientific Reports. 5, 10007.

Darina, D. H. X., Ová, and Prach, K., 2003. Spoil heaps from brown coal mining: technical reclamation versus spontaneous revegetation. Restoration Ecology. 11, 385-391.

Dai, W. H., Huang. Y., Wu, L. and Yu, J., 2009. Relationships between soil organic matter content (SOM) and pH in topsoil of zonal soils in China. Acta Pedologica Sinica. 5, 851-860.

Diazravina, M., and Baath, E., 1996. Development of metal tolerance in soil bacterial communities exposed to experimentally increased metal levels. Applied \& Environmental Microbiology. 62, 2970-7.

Dick, R. P., Myrold, D. D., and Kerle, E. A., 1988. Microbial biomass and soil enzyme activities in compacted and rehabilitated skid trail soils. Soil Science Society of America Journal. 52, $512-516$.

Du, X., Gao, X., and Ma, K., 2003. Diagnosis of the degree of degradation of an ecosystem: the basis and precondition of ecological restoration. Acta Phytoecologica Sinica. 27, 700-708.

Dulias, R., 2010. Landscape planning in areas of sand extraction in the Silesian Upland, Poland. Landscape \& Urban Planning. 95, 91-104.

Dunrud, C. R., and Osterwald, F. W., 1980. Effects of coal mine subsidence in the Sheridan, Wyoming, Area. Center for Integrated Data Analytics Wisconsin Science Center.

Ermite, C., Younger, P. L., and Wolkersdorfer, C., 2004. Mining impacts on the fresh water environment: technical and managerial guidelines for catchment scale management. Mine Water and the Environment. 23, s2-s80. 
Feng, Y., Grogan, P., Caporaso, J. G., Zhang, H., Lin, X., Knight, R., and Chu, H., 2014. pH is a good predictor of the distribution of anoxygenic purple phototrophic bacteria in Arctic soils. Soil Biology \& Biochemistry. 74, 193-200.

Fensham R J, Fairfax R J, Archer S R., 2005. Rainfall, land use and woody vegetation cover change in semi-arid Australian savanna. Journal of Ecology. 93, 596-606.

Fieldsjohnson, C. W., Zipper, C. E., Burger, J. A., and Evans, D. M., 2012. Forest restoration on steep slopes after coal surface mining in Appalachian USA: soil grading and seeding effects. Forest Ecology \& Management. 270, 126-134.

Fierer, N., and Jackson, R. B., 2006. The diversity and biogeography of soil bacterial communities. Proceedings of the National Academy of Sciences of the United States of America, 103, 626.

Fu, H. L., Wang, S. R., Han, S. J., Zhang, J. H., Zhang, H. H., and Dai, G. H., 2009. Influence of wet/dry cycle on soil microbial activity and community flora in broadleaved Korean pine forest in Changbai Mountains. Journal of Northeast Forestry University.

Garbeva, P., Postma, J., van Veen, J. A., and van Elsas, J. D., 2006. Effect of above-ground plant species on soil microbial community structure and its impact on suppression of Rhizoctonia solani AG3. Environmental Microbiology. 8, 233-246.

González, E., Masip, A., Tabacchi, E., and Poulin, M., 2016. Strategies to restore floodplain vegetation after abandonment of human activities. Restoration Ecology. 25, 82-91.

Gornish, E. S., Lennox, M. S., Lewis, D., Tate, K. W., and Jackson, R. D., 2017. Comparing herbaceous plant communities in active and passive riparian restoration. Plos One. 12, e0176338. 
Guo, G., Feng, B., Baolin, M. A., Zhang, Y., Guo, C., and Jing, Z., 2013. Leaf anatomical structures of different regional Amygdalus pedunculata Pall. and Their Drought Resistance Analysis. Acta Botanica Boreali-Occidentalia Sinica. 33, 720-728.

Hao, B., and Qi, J., 2009. Planning of land reclamation and ecological restoration in the coal mining subsidence areas of Wangwa Coal Mine. International Conference on Environmental Science and Information Application Technology, 214-217.

Hazarika, L. P., 2013. Diversity indices of macro invertebrates in the Satajan Wetland of Lakhimpur District, Assam. Annals of Biological Research. 4, 68.

Horn, D. J. V., Horn, M. L. V., Barrett, J. E., Gooseff, M. N., Altrichter, A. E., Geyer, K. M., Zeglin, L. H., Takacsvesbach, C. D., Horn, D. J. V., and Horn, M. L. V., 2013. Factors controlling soil microbial biomass and bacterial diversity and community composition in a cold desert ecosystem: role of geographic scale. Plos One. 8, e66103.

Hu, Z., Wang, P., and Li, J., 2012. Ecological restoration of abandoned mine land in China. Journal of Resources and Ecology. 3, 289-296.

Huang, H., Wang, C., Bai, H., Wang, Z., Huang, H., Wang, C., Bai, H., and Wang, Z., 2012. Water protection in the western semiarid coal mining regions of China: A case study. International Journal of Mining Science and Technology. 22, 719-723.

Hyvärinen, M., and Kauppi, P. H. M., 1992. Influence of stand age and structure on the Epiphytic Lichen Vegetation in the Middle-Boreal Forests of Finland. Lichenologist. 24, 165-180.

Juwarkar, A. A., Yadav, S. K., Thawale, P. R., Kumar, P., Singh, S. K., and Chakrabarti, T., 2009. Developmental strategies for sustainable ecosystem on mine spoil dumps: a case of study. 
Environmental Monitoring \& Assessment. 157, 471.

Kimball, S., Lulow, M., Sorenson, Q., Balazs, K., Fang, Y., Davis, S. J., O'Connell, M., and

Huxman, T. E., 2015. Cost-effective ecological restoration. Restoration Ecology. 23, 800-

810.

Koch, J. M., 2010. Restoring a Jarrah Forest Understorey Vegetation after Bauxite Mining in Western Australia. Restoration Ecology. 15, S26-S39.

Krümmelbein, J., and Raab, T., 2012. Development of soil physical parameters in agricultural reclamation after brown coal mining within the first four years. Soil \& Tillage Research. 125, 109-115.

Legendre, P., and Legendre, L., 1998. Numerical ecology, 2nd English edn. Developments in environmental modeling.

Lei, S., Ren, L., and Bian, Z., 2016. Time-space characterization of vegetation in a semiarid mining area using empirical orthogonal function decomposition of MODIS NDVI time series. Environmental Earth Sciences. 75, 516.

Li, S., Bi, Y. L., Kong, W., Yu, H., Lang, Q., and Miao, Y., 2015. Effects of arbuscular mycorrhizal fungi on ecological restoration in coal mining areas. Russian Journal of Ecology. $46,431-437$.

Li, W., Shaogang, L., and Zhengfu, B., 2017. Research framework for quantitative measurement of mine vegetation ecosystem resilience in multi scale. Journal of Arid Land Resources and Environment. 31, 76-80.

Li, X., Zhu, J., and Chang, J., 2006. Influence of coal exploitation on forest ecosystem in Shanxi. 
Science of Soil \& Water Conservation. 4, 36-41.

Li, Y., Bian, Z., Lei, S., and Liu, Y., 2017. Land damage evaluation in coal mining area with super-size mining face at western aeolian sandy area. Coal Science and Technology. 45, $188-194$.

Liu, H., Deng, K. Z., He, C. G., Sun, C. D., Dong, Z. L., and Zhang, A. B., 2013. Surface subsidence law of filling with super-high-water material and skip mining. Journal of China Coal Society. 38, 272-276.

Liu, X. M., 2011. Response of photosynthesis and chlorophy II fluorescence parameters to different drought stress in Cerasus humilis Bunge. Plant Physiology Journal.

Liu, Y., L. S. C. L., 2017. Effects of soil water content on stomatal conductance, transpiration, and photosynthetic rate of Caragana korshinskii under the influence of coal mining subsidence. Acta Ecologica Sinica, http://dx.doi.org/10.5846/stxb201703160442 (in press).

Morris, S. J., and Blackwood, C. B., 2015. Chapter 10-The ecology of the soil biota and their function. Soil Microbiology Ecology \& Biochemistry. 273-309.

Orsi, F., Geneletti, D., and Newton, A. C., 2011. Towards a common set of criteria and indicators to identify forest restoration priorities: An expert panel-based approach. Ecological Indicators. 11, 337-347.

Parton, W. J., Grosso, S. J. D., Plante, A. F., Adair, E. C., and Lutz, S. M., 2015. Chapter 17modeling the dynamics of soil organic matter and nutrient cycling. Soil Microbiology Ecology \& Biochemistry. 505-537.

Perillo, G. M. E., 2009. Coastal wetlands : an integrated ecosystem approach. 
Prach, K., Řehounková, K., Řehounek, J., and Konvalinková, P., 2011. Ecological restoration of central european mining sites: A summary of a Multi-site analysis. Landscape Research. 36, $263-268$.

Qian, M. G., 2011. Coal production expansion triggered midwest environmental worries. Resources environment and development. 4, 4-7.

Qi, H. Z., Hua, L. J., and Jing, W. X., 2014. Self-healing,natural restoration and artificial restoration of ecological environment for coal mining. Journal of China Coal Society. 39, $1751-1757$.

Ramette, A., 2007. Multivariate analyses in microbial ecology. Fems Microbiology Ecology. 62, $142-160$.

Ren, J. T., 2017. Biodiversity and distribution of AMF and other soil microorganisms of Aeolian sandy coal mining subsidence area, University of The Inner Mongol.

Saeki, K., Kunito, T., Oyaizu, H., and Matsumoto, S., 2002. Relationships between bacterial tolerance levels and forms of copper and zinc in soils. Journal of Environmental Quality. 31, $1570-1575$.

Sariyildiz, T., and Anderson, J. M., 2003. Interactions between litter quality, decomposition and soil fertility: a laboratory study. Soil Biology \& Biochemistry. 35, 391-399.

Scasta, J. D., Trostle, C. L., and Foster, M. A., 2012. Evaluating Alfalfa (Medicago sativa L.) cultivars for salt tolerance using laboratory, greenhouse and field methods. Journal of Agricultural Science 4.

Schulze, E. D., and Mooney, H. A., 1994. "Ecosystem function of biodiversity: a summary. 
Springer Berlin Heidelberg.

Sha, J. L., Jian, L. I., and Zhi-Gang, L. I., 2013. Effects of adding poplar and willow branches on organic carbon, moisture and microbial activities of sandy soil. Pratacultural Science. 30, $1308-1312$.

Sheoran, V., Sheoran, A. S., and Poonia, P., 2010. Soil Reclamation of abandoned mine land by revegetation: A Review. International Journal of Soil Sediment \& Water. 3.

Shi, G. Q., Zheng, R. Q., Wang, H. B., 2009. Population migration in ecologically fragile areas of Western China - immigration policy and practice of dual objectives of ecological environment protection and poverty alleviation. Seminar on Environmental Sociology in China.

Sparks, D. L., Page, A. L., Helmke, P. A., Loeppert, R. H., Soltanpour, P. N., Tabatabai, M. A., Johnston, C. T., and Sumner, M. E., 1996. Methods of soil analysis. Part III. chemical methods.

Sparks, D. L., Page, A. L., Helmke, P. A., Loeppert, R. H., Soltanpour, P. N., Tabatabai, M. A., Johnston, C. T., and Sumner, M. E., 2009. Methods of soil analysis. Part 3.chemical methods..

Stark, J. M., Firestone, M. K., Stark, J. M., and Firestone, M. K., 1995. Mechanisms for soil moisture effects on activity of nitrifying bacteria. Applied \& Environmental Microbiology. $61,218-21$.

Song, B. M., 2008. Ecological restoration of abandoned quarries in Xishan Mountain of Beijing: process, characteristics and mechanism of natural restoration, Shandong University. 
Sun, S. T., Wang, L., Che, K. J., 2016. Analysis of vegetation coverage change in Diebu Forest of the upper Bailong River Base on Landsat Satellite Data. Journal of Sichuan Agricultural University. 34, 39-47.

Tordoff, G. M., Baker, A. J. M., Willis, A. J., and Wong, M. H., 2000. Current approaches to the revegetation and reclamation of metalliferous mine wastes. Chemosphere. 41, 219-228.

Tropek, R., Kadlec, T., Hejda, M., Kocarek, P., Skuhrovec, J., Malenovsky, I., Vodka, S., Spitzer, L., Banar, P., and Konvicka, M., 2012. Technical reclamations are wasting the conservation potential of post-mining sites. A case study of black coal spoil dumps. Ecological Engineering. 43, 13-18.

Van Horn, D. J., Van Horn, M. L., Barrett, J. E., Gooseff, M. N., Altrichter, A. E., Geyer, K. M., Zeglin, L. H., and Takacsvesbach, C. D., 2013. Factors controlling soil microbial biomass and bacterial diversity and community composition in a Cold Desert Ecosystem: Role of Geographic Scale. Plos One. 8, e66103.

Wang, L., 2007. Planning methods of ecological restoration for coal mining area in China and its case study. Metal Mine.

Wang, P. J., Hu, Z. Q., Shao, F., Jiang, Z. D., Qiao, Z. Y., Liu, D. W., and Chen, Y. K., 2014. Feasibility analysis of Yellow River sediment used as the filling reclamation material of mining subsidence land. Journal of China Coal Society. 39, 1133-1139(7).

Wang, Q. C., and Wang, G. P., 2001. Research on characteristics of soil and water loss in coal mining area of Loess Plateau. Research of Soil \& Water Conservation.

Wang, Q., Fei, Y., Hao, S. P., and Chao-Hai, L. I., 2009. Effects of subsoil bulk density on 
rhizospheric soil microbial population,microbial biomass carbon and nitrogen of corn(Zea mays L.) field. Acta Ecologica Sinica. 29, 3096-3104.

Wang, Y., Zhang, Q., and Feng, Z., 2006. Current research status and prospects of ecological degeneration and restoration at the juncture of Shanxi,Shaanxi and Inner Mongolia. Chinese Journal of Ecology. 25, 703-706.

Wilsonkokes, L., Delong, C., Thomas, C., Emerson, P., O'Dell, K., and Skousen, J., 2013. Hardwood tree growth on amended mine soils in west virginia. Journal of Environmental Quality. 42, 1363-1371.

Wong, M. H., Chan, Y. S. G., Zhang, C., and Ng, C. W. W., 2016. Comparison of pioneer and native woodland species growing on top of an engineered landfill, Hong Kong: Restoration Programme. Land Degradation \& Development. 27, 500-510.

Worrall, R., Neil, D., Brereton, D., and Mulligan, D., 2009. Towards a sustainability criteria and indicators framework for legacy mine land. Journal of Cleaner Production. 17, 1426-1434.

Xiaofen, M. A., Wang, X., Qiang, L. I., and Xiao, H. E., 2013. The analysis of drought resistance and the comparison of anatomical structures of the leave of Xanthoceras sorbifolia Bunge introduced from different regions. Journal of Arid Land Resources \& Environment. 27, 92 96.

Xu, R. G., 2011. Study on diversity of AMF and quantitative characteristics of soil microorganisms in coal mining area, University of The Inner Mongol.

Yang, D., Bian, Z., and Lei, S., 2016. Impact on soil physical qualities by the subsidence of coal mining: a case study in Western China. Environmental Earth Sciences. 75, 1-14. 
Zak, D. R., Holmes, W. E., White, D. C., Peacock, A. D., and Tilman, D., 2003. Plant diversity, soil microbial communities, and ecosystem function: are there any links? Ecology. 84, 20422050.

Zhang, C. X., Li, X. U., and Zhou, X. C., 2007. Land suitability assessment of vegetation restoration of the coal gangue pile of Fuxin Mine Area. Research of Soil \& Water Conservation.

Zhang H, Qu J, Zhang K., 2015. Vegetation cover information extraction technology for Dunhuang Oasis Based on remotesensing images. Journal of Desert Research. 35, 493-498.

Zhou, J., and Wang, L., 2014. Comprehensive study on ecological restoration and land exploitation of mining subsidence in suburbs of Chinese mining cities. Journal of China Coal Society. 1, 248-252.

Zipper, C. E., Burger, J. A., Barton, C. D., and Skousen, J. G., 2013. Rebuilding soils on mined land for native forests in Appalachia. Soil Science Society of America Journal. 77, 337. 